Article

\title{
Coral Reef Socio-Ecological Systems Analysis \& Restoration
}

\author{
Natalia Uribe-Castañeda ${ }^{1,2, *}$, Alice Newton ${ }^{2,3}$ (1) and Martin Le Tissier ${ }^{4}$ \\ 1 Estuaries and Mangroves Ecology Research Group, Universidad del Valle, Cali, Colombia \\ 2 CIMA, Campus de Gambelas, Universidade do Algarve, 8005-139 Faro, Portugal; anewton@ualg.pt or \\ an@nilu.no \\ 3 NILU-IMPACT, Box 100, 2027 Kjeller, Norway \\ 4 Future Earth Coasts, MaREI, Environmental Research Institute, University College Cork, P43 C573 Cork, \\ Ireland; martin.letissier@ucc.ie \\ * Correspondence: natalia.uribe@correounivalle.edu.co
}

Received: 25 July 2018; Accepted: 30 October 2018; Published: 29 November 2018

\begin{abstract}
Restoration strategies for coral reefs are usually focused on the recovery of bio-physical characteristics. They seldom include an evaluation of the recovery of the socio-ecological and ecosystem services features of coral reef systems. This paper proposes a conceptual framework to address both the socio-ecological system features of coral reefs with the implementation of restoration activity for degraded coral reefs. Such a framework can lead to better societal outcomes from restoration activities while restoring bio-physical, social and ecosystem service features of such systems. We first developed a Socio Ecological System Analysis Framework, which combines the Ostrom Framework for analyzing socio-ecological systems and the Kittinger et al. human dimensions framework of coral reefs socio-ecological systems. We then constructed a Restoration of Coral Reef Framework, based on the most used and recent available coral reef restoration literature. These two frameworks were combined to present a Socio-Ecological Systems \& Restoration Coral Reef Framework. These three frameworks can be used as a guide for managers, researchers and decision makers to analyze the needs of coral reef restoration in a way that addresses both socio-economic and ecological objectives to analyze, design, implement and monitor reef restoration programs.
\end{abstract}

Keywords: coral restoration; ecosystem services; adaptive management; conceptual frameworks

\section{Introduction}

Tropical coral reefs supply a wide number of ecosystem services to coastal societies. Global estimates suggest that coral reefs ecosystem services are worth billions of dollars annually [1-7]. The most relevant ecosystem services delivered by coral reefs are provision of renewable resources (fisheries, materials for medicines, algae, live fish), shoreline protection, regulation of erosive processes, buildup of land, promoting growth of mangrove and seagrass beds, generation of coral sand, breakwater to reduce wave height, nursery and habitat, biodiversity and genetic library, nitrogen fixation and $\mathrm{CO}_{2} / \mathrm{Ca}$ control, resilience maintenance, aesthetic values, sustaining the livelihood of communities, support of diving, snorkeling, tourism, leisure opportunities, cultural and spiritual values [8-12].

Despite their importance, more than $40 \%$ of the world's tropical coral reef ecosystems have been progressively damaged over the last four decades $[13,14]$. The mortality experienced by coral ecosystems has been extensive, for instance, many bleaching events have altered coral reefs around the world [15-18]. Corals have been affected by global changes as the sea surface temperature rise [19-21] and ocean acidification [22]. In addition, corals have been affected by anthropogenic pressures 
such as overharvesting, destructive fishing, anchor damage, ship groundings, pollution, invasive species, storms, disease, eutrophication, sediment loads from agricultural, urbanized terrestrial catchments and coastal development. These cumulative pressures have had a deleterious effect on coral reefs ecosystems around the world [23-27]. Despite, their endangered status, coral reefs are still poorly protected or under traditional conservation management that are not achieving the desired goals [28-30].

The declaration of the Convention on Biological Diversity emphasizes that restoration is essential for rehabilitating the world's ecosystem functioning, goods and services [31]. Restoration has been defined as "the process of assisting the recovery of an ecosystem that has been degraded, damaged, or destroyed" [32]. There are different methods to restore a coral reef: asexual propagation, sexual propagation, coral gardening (asexual propagation using nurseries) and physical restoration. In this paper, we focus on the coral gardening restoration method, which may enhance the successful recovery of more than 90 species coral species around the world [14,30].

Socio-ecological systems (SES's) analysis focuses on the relationship between ecosystems and society [33,34]. It addresses how the social dynamics of demand and catchment of ecosystem services determine ecological integrity [35] and how both social and ecological systems respond to the pressures $[33,35,36]$. Studies have been demonstrated a close relation between the Socio-ecological Systems and the Ecosystem services [37]. Marine ecosystems, including coral reefs, are tightly linked to coastal, human communities and livelihoods [38]. Therefore, the holistic analysis of the SES's is necessary to develop management, conservation and restoration initiatives in those systems.

Restoration strategies and management instruments should be integrated with socio-ecological system assessments that provide key information to establish future interventions and strategies for practitioners, program monitoring and evaluation efforts [39-42].

The aim of this work was to design a framework that provides guidance to communities, researchers, managers and decision makers to analyze how coral reef restoration can be implemented in a way that addresses both social and ecological objectives in view of the vulnerability of these SES, [43].

\section{Methods}

A framework is a tool that links different ideas as a guide to understand a process. In this research, three frameworks were developed.

- SES's Framework: identifies the main subsystems, interactions and outcomes of a coral reef SES's.

- Restoration Framework: establishes the main steps to restore the ecological features of a Coral Reef.

- Combined Framework: combines the two previous frameworks for a holistic approach to address social and ecological objectives to analyze, design, implement and monitor reef restoration programs.

\subsection{SES's Framework}

The coral reef SES's Framework (Figure 1) was constructed using elements from the Ostrom (2009) framework for analyzing SES's and the Kittinger et al. (2012) human dimensions framework. The coral reef SES's framework was design using the Ostrom basic structure. The Ostrom subsystem 'Resource Unit' was identified as 'Ecosystem Services.' The Ostrom subsystem 'Governance system' is substituted to the 'Social System Traits' based on Kittinger et al. (2012) recommendations. The 'Human Modifying Actions' interaction was recommended by Kittinger et al. 2012, including both negative and positive actions. 


\subsection{Restoration Framework}

The coral reef Restoration Framework (Figure 2) used the structure of an adaptive management cycle [44]. Each stage of the adaptive management cycle was constructed selecting the successful findings and key recommendations ideas identified from the most cited and common used research papers and guidelines published on coral reef restoration in the last ten years. The publications selected are shown in Table 1.

Table 1. The most cited and common used coral reef restoration publications (last 10 years).

\begin{tabular}{|c|c|c|c|c|}
\hline Code & Type & Literature & Authors, Year & Tittle \\
\hline 1 & Guidelines & [45] & Marshall et al., 2015 & $\begin{array}{l}\text { A Reef Manager's Guide to Fostering } \\
\text { Community Stewardship }\end{array}$ \\
\hline 2 & Research paper & [46] & Rinkevich 2014 & $\begin{array}{l}\text { Rebuilding coral reefs: Does active reef } \\
\text { restoration lead to sustainable reefs? }\end{array}$ \\
\hline 3 & Research paper & [14] & Rinkevich, 2015 & $\begin{array}{l}\text { Climate change and active reef } \\
\text { restoration-ways of constructing the } \\
\text { "Reefs of Tomorrow." }\end{array}$ \\
\hline 4 & Research paper & [47] & Van Oppen et al., 2017 & $\begin{array}{l}\text { Shifting paradigms in restoration of the } \\
\text { world's coral reefs }\end{array}$ \\
\hline 5 & Guidelines & [48] & Edwards, 2010 & $\begin{array}{l}\text { Reef Restoration Concepts and Guidelines: } \\
\text { Making Sensible Management Choices in the } \\
\text { Face of Uncertainty }\end{array}$ \\
\hline 6 & Research paper & [49] & Berg et al., 2015 & $\begin{array}{l}\text { The Marine Strategy Framework Directive } \\
\text { and the ecosystem-based approach-pitfalls } \\
\text { and solutions }\end{array}$ \\
\hline 7 & Guidelines & [50] & Edwards and Gomez, 2007 & Reef Rehabilitation Manual. \\
\hline 8 & Review paper & [51] & Young et al., 2012 & $\begin{array}{c}\text { A review of reef restoration and coral } \\
\text { propagation using the threatened genus } \\
\text { Acropora in the Caribbean } \\
\text { and Western Atlantic }\end{array}$ \\
\hline 9 & Research paper & [30] & Rinkevich, 2008 & $\begin{array}{l}\text { Management of coral reefs: we have gone } \\
\text { wrong when neglecting active reef restoration } \\
\text { Fixed and suspended coral nurseries in the }\end{array}$ \\
\hline 10 & Research paper & [52] & Shaish et al., 2008 & $\begin{array}{l}\text { Philippines: Establishing the first step in the } \\
\text { "gardening concept" of reef restoration }\end{array}$ \\
\hline 11 & Research paper & [53] & Lirman and Schopmeyer, 2016 & $\begin{array}{l}\text { Ecological solutions to reef degradation: } \\
\text { optimizing coral reef restoration in the } \\
\text { Caribbean and Western Atlantic }\end{array}$ \\
\hline 12 & Research paper & [54] & Montoya-Maya et al., 2016 & $\begin{array}{l}\text { Large-scale coral reef restoration could assist } \\
\text { natural recovery in Seychelles, Indian Ocean }\end{array}$ \\
\hline 13 & Guidelines & [55] & Johnson et al., 2011 & $\begin{array}{l}\text { Caribbean Acropora restoration guide: best } \\
\text { practices for propagation and } \\
\text { population enhancement. }\end{array}$ \\
\hline
\end{tabular}

\subsection{Combined Framework}

The Combined Framework (Figure 3) couples the elements from the SES's Framework and the Restoration Framework. It therefore includes the basic social and ecological aspects for developing coral reef SES's analysis and restoration. The structure follows the adaptive management cycle approach [44]. Actions to restore the subsystems are suggested for each stage.

\section{Results}

\subsection{SES's Framework}

The SES's Framework is a guide to understand a coral reef SES (Figure 1). The principal subsystems are the 'Coral Reef (CR),' the 'Ecosystem Services (ES),' the 'Social System Traits (SST)' and the 'Users (U).' These subsystems interact in two principal ways through the 'Human Well-Being' and the 'Human Modifying Actions' components. The 'Human Well-Being' is provided by the 'Coral Reefs' through the provision of 'Ecosystem Services' to the 'Users.' In the other direction, the 'Human Modifying Actions' are produced by the 'Users' regulated by the 'Social System Traits' and ending in 'Coral Reef' changes. 
Finally, both interactions produce 'Environmental and Institutional Outcomes' in all the subsystems of the coral reef Socio-Ecological System.

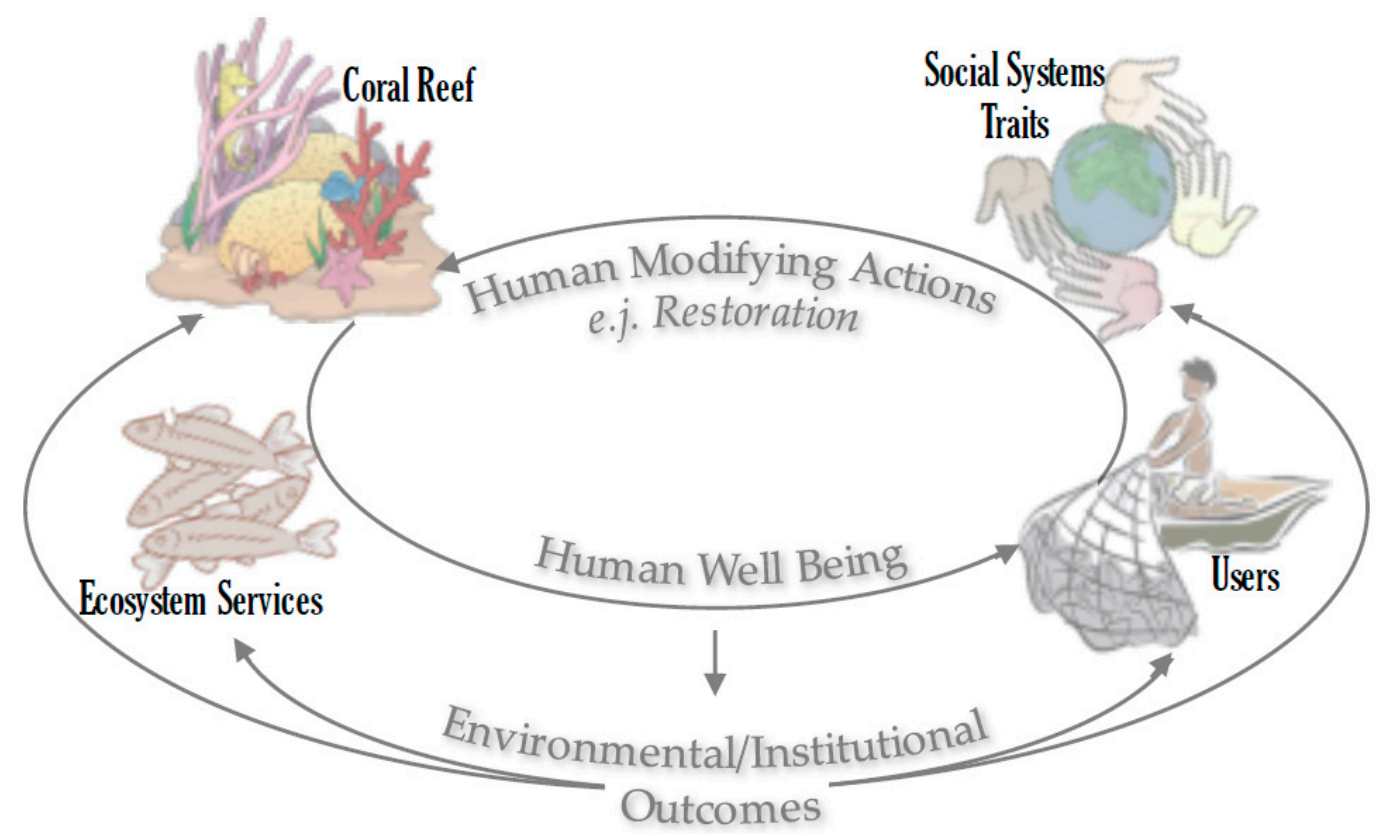

Figure 1. Coral reef SES's Framework: a guide to analyse coral reef social-ecological systems.

\subsection{Restoration Framework}

There are existing guidelines for the restoration of coral reefs, e.g. [56], on which we drawn to build our Restoration Framework. The Restoration Framework (Figure 2) is a guide to restore the ecological features of coral reef. The first phase of the framework is 'Assess' the initial ecological analysis of the coral reef. The second stage is 'Design,' to delimit a realistic size, select the species that are going to be restored, identify the best period of time and the adequate site on which to establish the nurseries and the outplantings. The 'Prepare' stage focuses on the activities that should be conducted before starting to implement the program. This includes the mitigation of coral reef pressures and capacity building workshops for all groups of users. The next stage is to 'Implement' the coral gardening. It consists of two steps: Nursery (set-up and collect the fragments) and Outplanting (select and attach the growth fragments). The fifth phase is 'Monitor' that includes the monitoring and the maintenance of the Outplanting. The last stage is 'Evaluate and adapt,' which is focused on evaluating whether the project goals have been reached and how to improve a next phase in the future. 


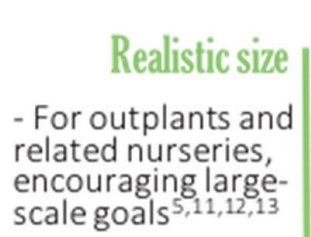

Species

- According reference sites ${ }^{4,5}$ - Robust variants and resistant genetic

scale goals $5,11,12,13$
Moment

- Avoid activities before stormy season,

when sea temperatures are high and

during the main aturning time $3,5,8,13$

Site with variable habic
genetic diversity

Wald and healthy coral populations, low: temperature

Coral state, larval supply, past bleaching events, disease outbreaks and consequences $2,4,7$; Diversity, endangered, commercial, and invasive species ${ }_{2,8,6}^{4,8}$. Water quality ${ }^{2,6,7}$. Pressures $^{2}$.
2, Climate change scenarios $^{2}$

Evaluate and improve the project

- Check the new state of the coral reef - Check the goals achievement - Analyze the monitoring results - Evaluate the progress and the success of the

Monitor outplants

Survivorship, health status, disease, predation and breakage donor corals, colony size, number of branches, total live tissue, donor live tissue, number of branch fragments tips $<1 \mathrm{~cm}$, maximum branch width. Set up and monitor control areas without active restoration, 2,45,711,13

\section{Maintenance outplantings}

Remove algae and fouling invertebrates corallivorous predators, accumulated sediment, and diseased corals or tissues. cha energo deprive: pressures, coral competitors and and achievable logistically places $1,2,3,5,8,13$.

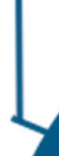

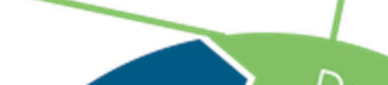

- Manage and mitigate reef pressures $2,5,8$

- Activities should be adaptive and flexible

to account for the inherent variability of

to account for the inherent variability of

\section{NURSERY Set-up}

- Use of mid-water rope nursery ease large-scale

projects, enhance coral growth rates, improve water

fluxes and reduce fouling proliferation $n^{2,3,5,13}$ - Distribute nurseries in different locations ${ }^{3,13}$

7 Collect

Deploy a nursery condition test ${ }^{13}$

Minimize handling, exposure to sunlight, 5,7,13

- Cut cleanly fragments $<3 \mathrm{~cm}$, less than $10 \%$ of donor

Use corals of opportunity 7,13

$$
\begin{array}{r}
\text { Repair damage and reattach fallen } \\
\text { fragments } 4,5,8,11,13 \\
\text { - Mix donor colonies in each outplanting site }{ }^{13}
\end{array}
$$

\section{Attach}

- Using masonry nails, epoxy, cement, wire, plastic cable ties or deploying reef sponges

Encourage self-attachment, juxtaposing

ving coral tissue to bare substrate ${ }^{7,12}$

Separate fragments $(50-100 \mathrm{~cm})^{2,13}$

-Transplant sexual colonies $>1 \mathrm{~cm}^{7}$

Figure 2. Coral reef Restoration Framework: a guide to restore a Coral Reef. (The literature used to develop this figure is related to the code number in Table 1). 


\subsection{Combined Framework}

The combined framework (Figure 3) is a guide to analyze and restore a coral reef SES. The important role of all the group of users and their key participation at all six projects stages is emphasized.

- Assess stage: consists of the assessment of the SES including ecological components, for example, larvae and social components, for example, users.

- Design stage: focuses on 'Ecosystem Services' provision with active 'Users' participation, linking with existing 'Social Systems Traits' and site selection, size and necessary time to develop the biophysical 'Coral Reef' restoration.

- Prepare stage: includes workshops with all groups of 'Users,' requests for permissions and mitigation of pressures.

- Implement stage: develop the 'Ecosystem Services' education campaigns, the 'Users' responsibilities, the 'Social Systems Traits' recommendations and policies and the biophysical 'Coral Reef' restoration through the recommended coral gardening approach.

- Monitor stage: consist of checking the development of activities conducted in the 'Implement' stage.

- Evaluate and adapt stage: 'Evaluate' the coral reef SES, verify whether the 'Ecosystem Services' goals have been achieved, check the 'Users' engagement, the 'Social Systems Traits' linking and the 'Coral Reef' state. Identify how the project should be adapted to improve in any subsequent phases.

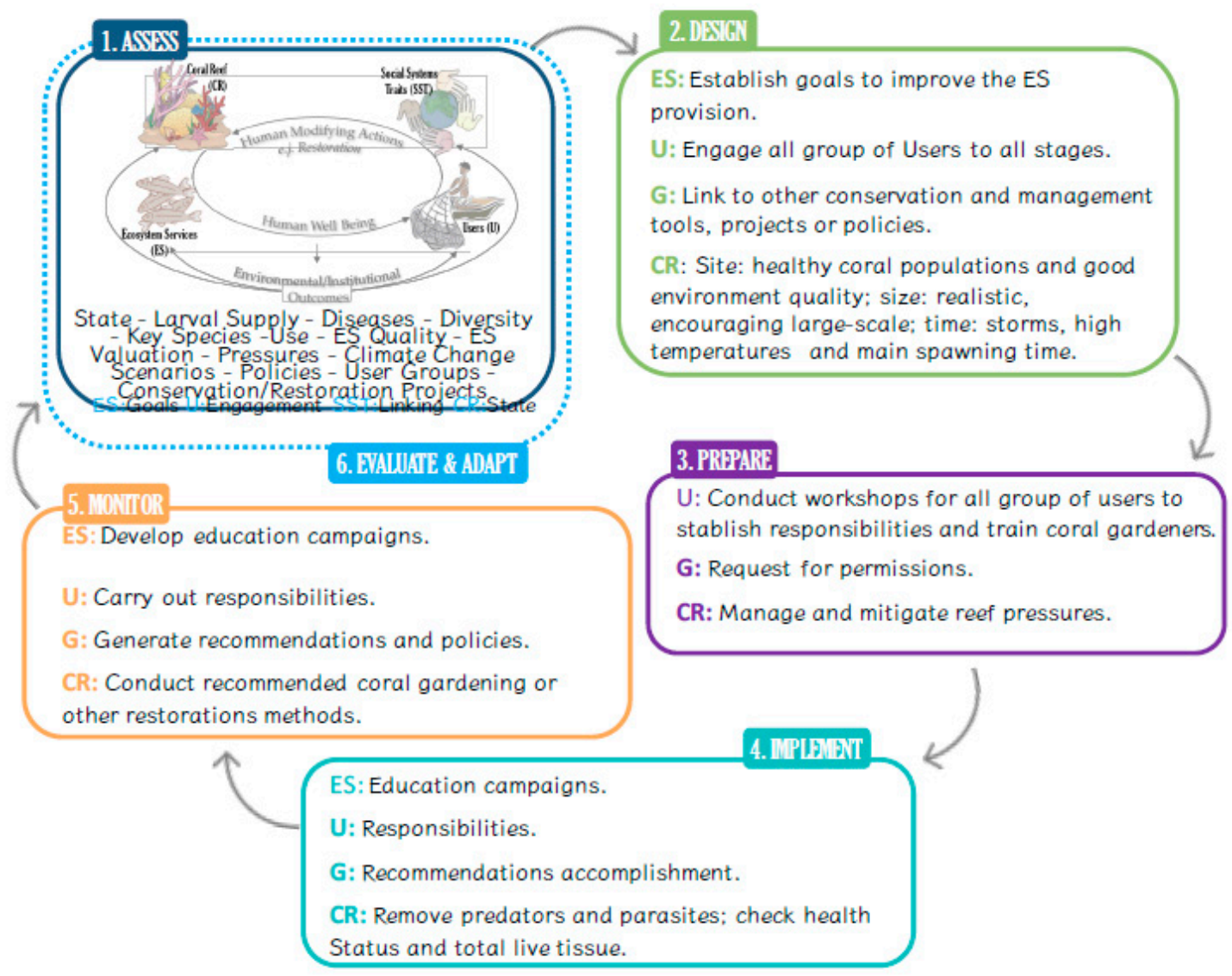

Figure 3. Coral reef Combined Framework: a guide to analyze and restore a Coral Reef SES's. 


\section{Discussion}

Restoration strategies and management instruments need to be integrated with socio-ecological system assessments in order to provide key information for establishing future interventions and strategies for practitioners, monitoring and evaluation programs [39-42]. Understanding SES is a difficult process, because ecological and social sciences have analyzed the SES's subsystems independently, so that combining them is not an easy task. General frameworks have been made for characterization of SES's [43,57-61]. Ostrom's [43] general framework is well known as a framework for analyzing SESs and she invited others to revise and further develop her SESs framework to enhance the sustainability of SES's. Developing more specific system approaches is necessary to achieve a better and more detail understanding of the Socio-Ecological Systems. Although the bio-physical characteristics of coral reefs are well studied, with a focus on conservation, research on social aspects of coral reef SES's systems is not as well developed. Therefore, enhanced efforts are needed to develop conceptual frameworks that could link different fields of research in order to comprehend, manage and restore coral reef SES's $[39,43,58,61]$. This paper has presented the SES's Framework as an attempt to analyze integrated coral reef SES's, in response to the challenges associated with using social-ecological science for marine conservation [62].

The main conservation, management and restoration objectives of the SES Framework developed is represented by the subsystem 'Ecosystem Services.' This new 'Ecosystem Services' approach on coral reef SES's analysis is the main difference of this framework compared with others that have been published (e.g., $[39,43])$. The 'Ecosystem Services' subsystem approach does not end with the delivery of human benefits, it simultaneously tackles healthy and productive ecosystems [63]. The subsystem 'Social System Traits' includes governance and other traits like demography, economy, technology and ethics. These traits can drastically modulate 'Users' activities, behavior and consumption and therefore has effects on 'Coral Reefs' and the 'Ecosystem Services' subsystems [39]. The SES Framework structure is simple, similar that the proposed by Ostrom [43], for ease of understanding which is useful and practical for decision makers and community members. In the Kittinger et al. framework [39], the 'Human Modifying Actions' interaction, can be understood as only negative effects. The 'Human Modifying Actions' includes both negative human effects as overharvesting, pollution, coral damage and so forth, as well as antagonist, positive actions such as resource stewardship, cultivation, restoration and management. The SES Framework presented is a simple and practical option for managers, researchers, community members and decision-makers to understand a coral reef SES in a holistic manner.

Although there is a lot of research published on coral reef restoration, this knowledge is not available in a way that can easily be used by managers, community members and decision-makers. The Restoration Framework was developed to overcome this. However, coral reef restoration has tended to be designed and evaluated from an ecology perspective. The majority of literature used to build the Restoration Framework was focused on restoring the bio-physical function of coral reefs and not the social, political and economic dimensions. The Combined Framework thus ensures that restoration can be designed in a way that meets both social and ecological criteria by combining the SES Framework and the Restoration Framework. The Combined Framework couples social and ecological criteria to analyze a coral reef SES's in order to develop successful restoration programs from both socio-economic and ecological perspectives. Additionally, this framework synthesizes not only a great quantity of literature related to coral reef restoration (Table 1) but also includes other key conservation and management approaches, such as the community-based management approach [63], the adaptive management cycle approach [44] and the millennium ecosystem assessment approach [57].

Users of the community-based management approach can witness their ability to protect and expand the resources which they depend on. Positive results of reef restoration are an empowering, educational tool to promote public awareness and participation in coral reef conservation, providing the foundation for community-based management and serving as a unification point between sometimes antagonistic user groups. In addition, the project continuity beyond the initial funding cycle will 
depend on the involvement of local stakeholders outside the scientific and management community, the adoption of propagation and restoration projects by dive shop operators, resort owners, fishermen and local communities were identified as key component to the long-term success of restoration programs [51].

The three frameworks (Combined Framework, SES Framework, Restoration Framework) developed in this research can be used as a guide for managers, researchers, community members and decision-makers for analyzing coral reefs SES's and for designing, implementing and monitoring successful and holistic restoration programs.

It is necessary to test the three frameworks in case studies and further field research using these frameworks will identify key features and possible improvements. These frameworks are guidelines and should be adapted to the specific case study characteristics. Changes, recommendations and modifications will contribute to improving the frameworks.

Author Contributions: Conceptualization, N.U.-C. and A.N. and M.L.T.; methodology, N.U.-C. and A.N. and M.L.T.; validation, N.U.-C. and A.N. and M.L.T.; formal analysis, N.U.-C. and A.N. and M.L.T.; investigation, N.U.-C. and A.N. and M.L.T.; resources, A.N; data curation, N.U.-C.; writing-original draft preparation, N.U.-C. writing-review and editing, A.N. and M.L.T. visualization, N.U.-C.; supervision, A.N. and M.L.T.; project administration, A.N.; funding acquisition, A.N.

Funding: This research was funded by European Commission, Erasmus Mundus programme and Future Earth Coasts.

Acknowledgments: We want to acknowledge to the Erasmus Mundus joint master program in Water and Coastal Management for funding Natalia Uribe-Castañeda for this research. Alice Newton acknowledges Future Earth Ocean KAN, IMBER and Future Earth Coasts. Martin LeTissier acknowledges Future Earth Coasts.

Conflicts of Interest: The authors declare no conflict of interest.

\section{References}

1. Moberg, F.; Folke, C. Ecological goods and services of coral reef ecosystems. Ecol. Econ. 1999, 29, 215-233. [CrossRef]

2. Costanza, R.; de Groot, R.; Sutton, P.; van der Ploeg, S.; Anderson, S.J.; Kubiszewski, I.; Farber, S.; Turner, R.K. Changes in the global value of ecosystem services. Glob. Environ. Chang. 2014, 26, 152-158. [CrossRef]

3. Costanza, R.; d'Arge, R.; de Groot, R.; Farber, S.; Grasso, M.; Hannon, B.; Limburg, K.; Naeem, S.; Oneill, R.V.; Paruelo, J.; et al. The value of the world's ecosystem services and natural capital. Nature 1997, 387, 253-260. [CrossRef]

4. Cesar, H.; Burke, L.; Pet-Soede, L. The Economics of Worldwide Coral Reef Degradation; Cesar Environmental Economics Consulting and WWF-Netherlands: Zeist, The Netherlands, 2003; pp. 12-15.

5. Bishop, R.C.; Chapman, D.J.; Kanninen, B.J.; Krosnick, J.A.; Leeworthy, B.; Meade, N.F. Total Economic Value for Protecting and Restoring Hawaiian Coral Reef Ecosystems: Final Report; NOAA Office of National Marine Sanctuaries, Office of Response and Restoration, and Coral Reef Conservation Program: Silver Spring, MD, USA, 2011; pp. 1-3.

6. Principe, P.; Bradley, P.; Yee, S.; Fisher, W.; Johnson, E.; Allen, P.; Campbell, D. Quantifying Coral Reef Ecosystem Services; NC.EPA/600/R-11/206; U.S. Environmental Protection Agency, Office of Research and Development: Research Triangle Park, NC, USA, 2011; pp. 1-5. Available online: www.researchgate.net/ publication/260339536_Quantifying_Coral_Reef_Ecosystem_Services (accessed on 26 November 2018).

7. Stoeckl, N.; Farr, M.; Larson, S.; Adams, V.M.; Kubiszewski, I.; Esparon, M.; Costanza, R. A new approach to the problem of overlapping values: A case study in Australia's Great Barrier Reef. Ecosyst. Serv. 2014, 10, 61-78. [CrossRef]

8. Whittingham, E.; Campbell, J.; Townsley, P. Poverty and Reefs: Volume 1: A Global Overview; DFID-IMM-IOC/UNESCO; Intergovernmental Oceanographic Commission of UNESCO: Paris, France, 2003; p. 4.

9. Hoegh-Guldberg, O.; Hughes, L.; Mcintyre, S.; Lindenmayer, D.B.; Parmesan, C.; Possingham, H.P.; Thomas, C.D. Assisted colonization and rapid climate change. Science 2008, 321, 345-346. [CrossRef] [PubMed] 
10. Ahmed, M.; Umali, G.M.; Chong, C.K.; Rull, M.F.; Garcia, M.C. Valuing recreational and conservation benefits of coral reefs-The case of Bolinao, Philippines. Ocean. Coast. Manag. 2007, 50, 103-118. [CrossRef]

11. Koch, E.W.; Barbier, E.B.; Silliman, B.R.; Reed, D.J.; Perillo, G.M.; Hacker, S.D.; Granek, E.F.; Primavera, J.H.; Muthiga, N.; Polasky, S.; et al. Non-linearity in ecosystem services: Temporal and spatial variability in coastal protection. Front. Ecol. Environ. 2009, 7, 29-37. [CrossRef]

12. Aswani, S.; Mumby, P.J.; Baker, A.C.; Christie, P.; McCook, L.J.; Steneck, R.S.; Richmond, R.H. Scientific frontiers in the management of coral reefs. Front. Mar. Sci. 2015, 2, 50. [CrossRef]

13. Burke, L.; Reytar, K.; Spalding, M.; Perry, A. Reefs at Risk Revisited; World Resources Institute: Washington, DC, USA, 2011; pp. 38-41, ISBN 978-1-56973-762-0.

14. Rinkevich, B. Climate change and active reef restoration-Ways of constructing the "Reefs of Tomorrow". J. Mar. Sci. Eng. 2015, 3, 111-127. [CrossRef]

15. Eakin, C.M.; Liu, G.; Gomez, A.M.; De La Cour, J.L.; Heron, S.F.; Skirving, W.J.; Geiger, E.F.; Tirak, K.V.; Strong, A.E. Global coral bleaching 2014-2017: Status and an appeal for observations. Reef Encount. 2016, 31, 20-26.

16. Normile, D. El Niño's warmth devastating reefs worldwide. Science 2016, 352, 15-16. [CrossRef] [PubMed]

17. Great Barrier Reef Marine Park Authority. Interim Report: 2016 Coral Bleaching Event on the Great Barrier Reef; GBRMPA: Townsville, Australia, 2017; pp. 24-27, ISBN 9780995373167.

18. The Conversation. How Much Coral Has Died in the Great Barrier Reef's Worst Bleaching Event? 2016. Available online: https:/ / theconversation.com/how-much-coral-has-died-in-the-great-barrier-reefs-worstbleaching-event-69494 (accessed on 26 November 2018).

19. Hönisch, B.; Ridgwell, A.; Schmidt, D.N.; Thomas, E.; Gibbs, S.J.; Sluijs, A.; Zeebe, R.; Kump, L.; Martindale, R.C.; Greene, S.E.; Kiessling, W. The geological record of ocean acidification. Science 2012, 335, 1058-1063. [CrossRef] [PubMed]

20. Wright, J.D.; Schaller, M.F. Evidence for a rapid release of carbon at the Paleocene- Eocene thermal maximum. Proc. Natl. Acad. Sci. USA 2013, 110, 15908-15913. [CrossRef] [PubMed]

21. Zeebe, R.E.; Dickens, G.R.; Ridgwell, A.; Sluijs, A.; Thomas, E. Onset of carbon isotope excursion at the Paleocene-Eocene thermal maximum took millennia, not 13 years. Proc. Natl. Acad. Sci. USA 2014, 111, 1062-1063. [CrossRef] [PubMed]

22. Albright, R.; Caldeira, L.; Hosfelt, J.; Kwiatkowski, L.; Maclaren, J.K.; Mason, B.M.; Rivlin, T. Reversal of ocean acidification enhances net coral reef calcification. Nature 2016, 531, 362-365. [CrossRef] [PubMed]

23. Andersson, A.J.; Gledhill, D. Ocean acidification and coral reefs: Effects on break-down, dissolution, and net ecosystem calcification. Ann. Rev. Mar. Sci. 2013, 5, 321-348. [CrossRef] [PubMed]

24. Hughes, T.P.; Baird, A.H.; Bellwood, D.R.; Card, M.; Connolly, S.R.; Folke, C.; Grosberg, R.; Hoegh-Guldberg, O.; Jackson, J.B.; Kleypas, J.; et al. Climate change, human impacts, and the resilience of coral reefs. Science 2003, 301, 929-933. [CrossRef] [PubMed]

25. Pandolfi, J.M.; Bradbury, R.H.; Sala, E.; Hughes, T.P.; Bjorndal, K.A.; Cooke, R.G.; McArdle, D.; McClenachan, L.; Newman, M.J.; Paredes, G.; et al. Global trajectories of the long-term decline of coral reef ecosystems. Science 2003, 301, 955-958. [CrossRef] [PubMed]

26. Grimsditch, G.D.; Salm, R.V. Coral Reef Resilience and Resistance to Bleaching; IUCN Resilience Science Group Working Paper Series; IUCN: Gland, Switzerland, 2006; pp. 6-8, ISBN 2-8317-0950-4.

27. Parmesan, C. Ecological and evolutionary responses to recent climate change. Annu. Rev. Ecol. Evol. Syst. 2006, 37, 637-669. [CrossRef]

28. Wilkinson, C. Status of Coral Reefs of the World: 2008; Global Coral Reef Monitoring Network and Reef and Rainforest Research Centre: Townsville, Australia, 2008; pp. 5-7.

29. Bruno, J.F.; Selig, E.R.; Casey, K.S.; Page, C.A.; Willis, B.L.; Harvell, C.D.; Sweatman, H.; Melendy, A.M. Thermal stress and coral cover as drivers of coral disease outbreaks. PLoS Biol. 2007, 5, 1220-1227. [CrossRef] [PubMed]

30. Shafir, S.; Rinkevich, B. The Underwater Silviculture Approach for Reef Restoration: An Emergent Aquaculture Theme. In Aquaculture Research Trends; Schwartz, S.H., Ed.; Nova Science Publications: New York, NY, USA, 2009; pp. 279-295.

31. Rinkevich, B. Management of coral reefs: We have gone wrong when neglecting active reef restoration. Mar. Pollut. Bull. 2008, 56, 1821-1824. [CrossRef] [PubMed] 
32. Normile, D. UN Biodiversity Summit yields welcome and unexpected progress. Science 2010, 330, 742-743. [CrossRef] [PubMed]

33. Society for Ecological Restoration Science and Policy Working Group. The SER Primer on Ecological Restoration. 2004. Available online: https:/ / www.ser-rrc.org/resource/the-ser-international-primer-on/ (accessed on 26 November 2018).

34. Collins, S.L.; Carpenter, S.R.; Swinton, S.M.; Orenstein, D.E.; Childers, D.L.; Gragson, T.L.; Grimm, N.B.; Grove, J.M.; Harlan, S.L.; Kaye, J.P.; et al. An integrated conceptual framework for long-term social-ecological research. Front. Ecol. Environ. 2011, 9, 351-357. [CrossRef]

35. Bodin, O.; Tengö, M. Disentangling intangible social-ecological systems. Glob. Environ. Chang. 2012, 22, 430-439. [CrossRef]

36. Burkhard, B.; Kroll, F.; Nedkov, S.; Müller, F. Mapping ecosystem service supply, demand and budgets. Ecol. Indic. 2012, 21, 17-29. [CrossRef]

37. Beier, C.M.; Patterson, T.M.; Chapin, F.S. Ecosystem services and emergent vulnerability in managed ecosystems: A geospatial decision-support tool. Ecosystems 2008, 11, 923-938. [CrossRef]

38. Nassl, M.; Löffler, J. Ecosystem services in coupled social-ecological systems: Closing the cycle of service provision and societal feedback. Ambio 2015, 44, 737-749. [CrossRef] [PubMed]

39. Teh, L.S.; Teh, L.C.; Sumaila, U.R. A global estimate of the number of coral reef fishers. PLoS ONE 2013, 8, e65397. [CrossRef] [PubMed]

40. Kittinger, J.N.; Finkbeiner, E.M.; Glazier, E.W.; Crowder, L.B. Human dimensions of coral reef social-ecological systems. Ecol. Soc. 2012, 17, 17. [CrossRef]

41. Abelson, A.; Halpern, B.S.; Reed, D.C.; Orth, R.J.; Kendrick, G.A.; Beck, M.W.; Nelson, P.A. Upgrading Marine Ecosystem Restoration Using Ecological-Social Concepts. BioScience 2015, 66, 156-163. [CrossRef] [PubMed]

42. Kittinger, J.N.; Bambico, T.M.; Minton, D.; Miller, A.; Mejia, M.; Kalei, N.; Wong, B.; Glazier, E.W. Restoring ecosystems, restoring community: Socioeconomic and cultural dimensions of a community-based coral reef restoration project. Reg. Environ. Chang. 2016, 16, 301-313. [CrossRef]

43. Berrouet, L.M.; Machado, J.; Villegas-Palacio, C. Vulnerability of socio-Ecological systems: A conceptual Framework. Ecol. Indic. 2018, 84, 632-647. [CrossRef]

44. Ostrom, E. A general framework for analyzing sustainability of social-ecological systems. Science 2009, 325, 419-422. [CrossRef] [PubMed]

45. Berkes, F.; Colding, J.; Folke, C. Rediscovery of traditional ecological knowledge as adaptive management. Ecol. Appl. 2000, 10, 1251-1262. [CrossRef]

46. Marshall, P.A.; Dowd, A.M.; Luder, C.; Maynard, J.A.; Beeden, R. A Reef Manager's Guide to Fostering Community Stewardship; IUCN: Gland, Switzerland, 2015; pp. 1-76, ISBN 978-2-8317-1771-5.

47. Rinkevich, B. Rebuilding coral reefs: Does active reef restoration lead to sustainable reefs? Curr. Opin. Environ. Sustain. 2014, 7, 28-36. [CrossRef]

48. Van Oppen, M.J.H.; Gates, R.D.; Blackall, L.L.; Cantin, N.; Chakravarti, L.; Chan, Y.; Cormick, C.; Crean, A.; Damjanovic, K.; Epstein, H.; et al. Shifting paradigms in restoration of the world's coral reefs. Glob. Chang. Biol. 2017, 1-12. [CrossRef] [PubMed]

49. Edwards, A.J. Reef Rehabilitation Manual; Coral Reef Targeted Research \& Capacity Building for Management Program: St. Lucia, Australia, 2010; pp. 1-166, ISBN 978-1-921317-05-7.

50. Berg, T.; Fürhaupter, K.; Teixeira, H.; Uusitalo, L.; Zampoukas, N. The Marine Strategy Framework Directive and the ecosystem-based approach-pitfalls and solutions. Mar. Pollut. Bull. 2015, 96, 18-28. [CrossRef] [PubMed]

51. Edwards, A.J.; Gomez, E.D. Reef Restoration Concepts and Guidelines: Making Sensible Management Choices in the Face of Uncertainty; Coral Reef Targeted Research \& Capacity Building for Management Program: St. Lucia, Australia, 2007; pp. 1-37, ISBN 978-1-921317-00-2.

52. Young, C.N.; Schopmeyer, S.A.; Lirman, D. A review of reef restoration and coral propagation using the threatened genus Acropora in the Caribbean and Western Atlantic. Bull. Mar. Sci. 2012, 88, 1075-1098. [CrossRef]

53. Shaish, L.; Levi, G.; Katzir, G.; Rinkevich, B. Coral reef restoration (Bolinao, the Philippines) in the face of frequent natural catastrophes. J. Soc. Ecol. Res. 2010, 18, 285-299. [CrossRef] 
54. Lirman, D.; Schopmeyer, S. Ecological solutions to reef degradation: Optimizing coral reef restoration in the Caribbean and Western Atlantic. PeerJ 2016, 4, e2597. [CrossRef] [PubMed]

55. Montoya-Maya, P.H.M.; Smit, K.P.; Burt, A.J.; Frias-Torres, S. Large-scale coral reef restoration could assist natural recovery in Seychelles, Indian Ocean. J. Nat. Conserv. 2016, 16, 1-17. [CrossRef]

56. Johnson, M.E.; Lustic, C.; Bartels, E.; Baums, I.B.; Gilliam, D.S.; Larson, E.A.; Lirman, D.; Miller, M.W.; Nedimyer, K.; Schopmeyer, S. Caribbean Acropora Restoration Guide: Best Practices for Propagation and Population Enhancement; The Nature Conservancy: Arlington, VA, USA, 2011; pp. 1-64.

57. Millennium Ecosystem Assessment (MEA). Ecosystems and Human Well-Being: Synthesis; Island Press: Washington, DC, USA, 2005; pp. 92-101, ISBN 1-59726-040-1.

58. Turner, B.L., II; Kasperson, R.E.; Matson, P.A.; McCarthy, J.J.; Corell, R.W.; Christensen, L.; Eckley, N.; Kasperson, J.X.; Luers, A.; Martello, M.L.; et al. A framework for vulnerability analysis in sustainability science. Proc. Natl. Acad. Sci. USA 2003, 100, 8074-8079. [CrossRef] [PubMed]

59. Redman, C.L.; Grove, J.M.; Kuby, L.H. Integrating social science into the long-term ecological research (LTER) network: Social dimensions of ecological change and ecological dimensions of social change. Ecosystems 2004, 7, 161-171. [CrossRef]

60. Ostrom, E. A diagnostic approach for going beyond panaceas. Proc. Natl. Acad. Sci. USA 2007, 104, 15181-15187. [CrossRef] [PubMed]

61. Norgaard, R.B. Finding hope in the millennium ecosystem assessment. Conserv. Biol. 2008, 22, 862-869. [CrossRef] [PubMed]

62. Leenhardt, P.; Teneva, L.; Kininmonth, S.; Darling, E.; Cooley, S.; Claudet, J. Challenges, insights and perspectives associated with using social-ecological science for marine conservation. Ocean. Coast. Manag. 2015, 115, 49-60. [CrossRef]

63. McLeod, K.L.; Leslie, H. Ecosystem-Based Management for the Oceans; Island Press: Oregon City, OR, USA, 2009; pp. 181-190, ISBN 1610911318.

(C) 2018 by the authors. Licensee MDPI, Basel, Switzerland. This article is an open access article distributed under the terms and conditions of the Creative Commons Attribution (CC BY) license (http:// creativecommons.org/licenses/by/4.0/). 